\title{
New Exploration of Innovation and Entrepreneurship Education in Colleges and Universities
}

Hua Lan

College Students' Entrepreneurship Guidance Center of Neijiang Normal University, Neijiang, 641100, China

$$
\text { 1742244397@qq.com }
$$

Keywords: Colleges and universities; Innovation and entrepreneurship education; Current situation; Strategies

Abstract. Under the background of building an innovative national development strategy in China, the innovation and entrepreneurship education has become the most important part of the talents training in various colleges and universities. However, in view of the reality of innovation and entrepreneurship education in colleges and universities, there are still some problems, for example, the positioning is inaccurate, most colleges and universities do not set up independent institutions, innovation and entrepreneurship education curriculum is not perfect, the outstanding teachers of innovation and entrepreneurship education are seriously deficient, and so on. Colleges and universities need to improve their understanding of innovation and entrepreneurship education, improve innovation and entrepreneurship education institutions, promote the reform of the innovation and entrepreneurship education curriculum system, and strengthen the construction of the teaching staff of innovation and entrepreneurship education, so as to improve the level of innovation and entrepreneurship education in China's colleges and universities, and provide innovative and entrepreneurial talents for the economic development of our country.

\section{高校创新创业教育新探}

\author{
兰华 \\ 内江师范学院大学生创业指导中心，中国 内江，641100
}

1742244397@qq.com

摘要: 在我国建设创新型国家发展战略背景下，创新创业教育成为各高校人才培养的重中之重。但就目前高校创新创业 教育的实际来看, 还存在定位不准确、多数高校未设置独立的机构、创新创业教育课程设置不够完善及创新创业教育优秀教 师严重贵乏等不足。还需要各高校提高对高校创新创业教育的认识、健全高校创新创业教育机构、推进高校创新创业教育课 程体系改革及加强高校创新创业教育师资队伍建设, 从而不断提高我国高校创新创业教育的水平, 为我国经济发展提供创新 创业的精英人才。

关键词：高校；创新创业教育；现状；对策

\section{1 引言}

我国目前正处在一个 “大众创业，万众创新” 的新时代背景之下，世界各国的创新竞争力已成为综合 国力较量的重要部分, 科技创新带动经济发展, 各个国家都十分重视。早在《国家中长期教育改革和发展 规划纲要 (2010一 2020 年)》中就明确提出: “改革人才培养模式, 把大学生创新精神与创业能力作为培养 核心，使创新创业教育与人才培养相融合”.李克强在 2014 年夏季达沃斯论坛上提出要在 960 万平方公 里土地上掀起大众创业、草根创业的新浪潮，形成万众创新、人人创新的新态势， 2014 年被誉为 “中国 创业元年”。2015 年 4 月 27 日国务院以国发 23 号印发关于进一步做好新形势下就业创业工作意见， 
文件指出：“大众创业、万众创新是富民之道、强国之路，必须着力创立大众创业、万众创新的新引擎。” 2016 年, 教育部印发的《关于做好 2016 届全国普通高等学校毕业生就业创业工作的通知》提出, 从 2016 年起所有高校都要设置创新创业教育课程。2017 年 2 月 4 日, 教育部发布的《普通高等学校学生管理规 定》也明确提出, 学校应当鼓励、支持和指导学生参加社会实践、创新创业活动, 可以建立创新创业档案, 设置创新创业学分。近年来, 国家出台了 “大众创业、万众创新” 的相关政策, 将大学生创业推向了一个 新的高潮。构建新型创新创业教育平台, 提升大学生创新创业能力系统化、规模化, 探索形式多样的社会 实践和创新创业项目, 是建设创新型国家的战略需要, 也是高等教育改革的迫切需要, 更是大学生就业和 成长成才的客观需要, 因此, 创新创业教育成为各高校人才培养的重中之重。

\section{2 高校创新创业教育的现状}

\section{1 高校创新创业定位不准确}

由于我国高校传统的教育方式是以授业解惑为主, 重点关注学生对知识技能的学习, 很少涉及培养学 生的创新创业技能以及对学生开展创新创业教育。所以我们现在还存在部分高校对创新创业教育的重视程 度不够, 同时也存在认识上的偏差。主要进行基础教育的高校认为创新创业教育是理工科等技术型、研究 型院校的事, 与基础教育的关系不大, 从而忽略了创新创业教育对毕业生以及国家发展战略的重要性; 而 那些毕业生就业情况较好的王牌高校, 由于其毕业生供不应求, 暂时未出现就业难得情形, 他们就更不愿 分出精力来进行创新创业教育。

\section{2 多数高校未设置独立的机构}

就高校当前进行创新创业教育的实际来看, 多数高校并未设置相对独立的机构, 专门从事创新创业教 育。大多数高校的创新创业教育一般都由学校的招生就业处负责, 即使某些高校成立就业指导中心等机构 也并未单独设置, 要么是挂靠学校教务处, 要么是挂靠学校招生就业处。由于没有相对独立的专门机构, 造成创新创业教育责任不明晰, 各种政策执行不能及时完全到位, 对已创业在校学生或参加创业实践学生 的支持力度还有不够。同时, 创新创业学生也面临着进行创新创业时间与专业教学时间冲突的矛盾无法解 决, 创新创业学分学时无法抵扣等问题, 从而对热衷于创新创新创业学生存在很大的制约, 在很大程度上 打消了学生在校期间创新创业想法, 同时也错过了市场机遇。

\section{3 高校创新创业教育课程设置不够完善}

目前, 高校创新创业教育课程设置还未形成一套成熟的体系, 还不够系统和完善。高校创新创业教育 课程通常以第二课堂或选修课的形式出现, 大多都在晚上或周末上课, 课程设置相对不够连贯, 且学时数 相对较少; 同时目前高校开展学生创新创业形式较为单一, 学生多以参加 “互联网+” “挑战杯” 大学生 创业竞赛等各类创业竞赛来增加创新创业实践经验, 除此而外就很少获得实践的机会。

\section{4 高校创新创业教育优秀教师严重黄乏}

高校创新创业教育师资队伍质量的高低直接决定高校创新创业教育的最终成效，因为他们是高校创新 创业教育的主体, 其直接参与和管理高校的创新创业教育活动。然而就我国高校的实际情况而言, 首先, 我国高校中大多数从事创新创业教育的教师是兼职教师, 他们自身都缺乏系统全面的知识体系结构, 且他 们也很难全身心地投入到对创新创业教育的研究和创新中, 导致我们开设的创新创业教育课程只是走过 场、完成任务, 很难达到应有的效果; 其次, 大多数高校缺乏有实践经验的 “双师型” 教师, 从事创新创 
业教育的教师几乎都是从原来的纯理论教学转型而来, 严重缺乏必要的实践经验, 对大学生的创新创业实 践指导性不足、时效性不高; 还有就是我们很多高校为了弥补自身师资力量的不足, 从而聘请企业家或创 业校友等来校担任创业导师, 虽然他们有着丰富的实践经验, 但是由于他们时间和精力有限, 很难及时满 足大学生的知识和技能需求。

\section{3 高校创新创业教育的发展对策}

\section{1 提高对高校创新创业教育的认识}

高校开展创新创业教育其根本目的不仅仅是为了缓解高校毕业生就业压力问题, 而是国家着眼于长远 发展需要。各高校应立足于国家创新型发展战略要求, 不断提高对创新创业教育重要性的认识, 加大对创 新创业教育工作的重视, 从而为国家和社会培养出更多优秀的创新创业人才, 不断推进国家创新型发展战 略的实现和社会的不断进步。

\section{2 健全高校创新创业教育机构}

一个相对独立的机构是保证高校创新创业教育有序发展的必然需要, 首先这样可以有专门的人员来思 考创新创业教育, 可以根据自身的实际设置出科学、完整的创新创业教育课程体系。其次这样可以有专门 的机构来推动创新创业教育的开展, 使其具有连贯性和系统性, 从而保证创新创业教育的效果。所以高校 应结合自身的实际, 设置具有相对独立性的创新创业教育机构, 从而保证我们的各种创新创业政策能得到 有效的执行, 我们有志于从事创新创业的学生能获得及时的引导和帮助。

\section{3 推进高校创新创业教育课程体系改革}

首先, 构建递进式结构的创新创业教育体系。各高校应根据自身的实际, 为学生设计出一套全过程、 递进式的创新创业教育体系, 使得学生在其大学生涯能科学的接受从职业生涯规划到创新创业技能培训等 一整套的系统训练。其次, 应将创新创业教育贯穿于专业课人才培养方案。在整合各学科基础知识上, 对 创新创业教育课程的教学目标、教学方法、教学内容进行重新定位, 从根本上解决教育课程 “大拼盘” 的 现状, 为实现创新创业教育目标创造良好条件。最后, 更新创新创业教育课程的理论和方法。高校在创新 创业教育人才培养过程中, 要严格教材选用制度, 加快更新教学内容的速度, 用最前沿的技术和理论作为 创新创业课程的主要授课内容。在授课中还要有意识地培养学生获取前沿信息的能力, 努力做到 “授人以 鱼不如授人以渔”。在教学方法中, 尝试采取 “学一做一创” 等教学方式, 保证学生能创新、能创业。

\section{4 加强高校创新创业教育师资队伍建设}

要做好高校的创新创业教育, 培养出适应社会需求的创新创业人才, 就必须打造一支理论丰富、技术 过硬的教师队伍。首先, 应该重视对现有师资队伍的培训提升工作, 通过多形式、多渠道的专题业务培训、 不定期经验交流等方式, 不断提升现有师资队伍的理论水平。高校还应加大选派相关专业人员到企业锻炼 的力度, 不断加强 “双师型” 人才的培养, 从而不断增强创新创业教学的实用性和实践指导的有效性。其 次, 高校还应加强相关人才的引进力度, 根据本地区和高校自身的实际制订出人才柔性引进计划, 为特殊 人才制定特殊的政策, 从而吸纳更多具有丰富实践经验的人才参加到创新创业培养工作中。最后, 高校还 应聘请创业教育专家、企业家、成功创业校友作为 “创业导师”, 这样既可以鲜活的实例来激发大学生创 新创业的热情, 也可在很大程度上弥补高校自身师资的不足。 


\section{4 结语}

大学生创新创业教育是一项长期复杂和艰巨的系统工程, 需要高校教育工作者和学生的共同努力, 需 要个人、社会、学校等多方面的密切配合。高校在创新创业教育改革进程中, 要在原有办学特色的基础上, 发挥自身优势, 不能蜂拥而上地搞全民运动。应根据学校自身实际作好创新创业教育课程的顶层设计, 制 定适合本校实际的创业课程体系和创新创业课程设置, 促进学生发挥创新创业的潜力, 助力学生开启创业 之路, 为我国经济发展提供创新创业的精英人才。

\section{参考文献:}

[1] 张继延，周屹峰. 高校创新创业人才的协同培养研究 [J]。国家教育行政学院学报，2016，(7)：61-66.

[2] 张兄武. 高校创新创业人才多元协同培养机制的构建 $[J]$. 国家教育行政学院学报，2016，(4)：30-37.

[3] 曾媛媛，罗秋兰．高校创新创业教育现状及发展策略 [J]．广西社会科学，2017，（4）：215-217.

[4] 曹明．应用型本科高校创新创业人才培养模式初探 [J]。中国大学教学，2011，（11）：35-36.

［5］杨柳青，李蔚然．高校创新创业人才培养现状调查分析 [J]．学校党建与思想教育，2017，（16）：80-82.

[6] 吴爱华, 侯永峰, 郝杰等. 以”互联网 + "双创大赛为载体深化高校创新创业教育改革 $[\mathrm{J}]$. 中国大学教学, 2017, (1) : 23-27.

[7] 廖琪丽，孟秀霞. 高校创新创业教育模式的实践探索 [J]。学校党建与思想教育，2017，（4 )：74-75，93.

\section{References}

[1] J.Y.Zhang and Y.F.Zhou: A Research on the Cooperative Cultivation of Innovation and Entrepreneurial Talents in Colleges and Universities[J], Journal of National Academy of Education, 2016,(7):61-66.(In Chinese)

[2] X.W.Zhang: The Construction of Multiple Cooperative Training Mechanism of Innovation and Entrepreneurship Talents in Colleges and Universities[J], Journal of National Academy of Education Administration, 2016,(4):30-37.(In Chinese)

[3] Y.Y.Zeng and Q.L.Luo: The Current Situation and Development Strategy of Innovation and Entrepreneurship Education in Colleges and Universities[J], Guangxi Social Sciences, 2017,(4):215-217.(In Chinese)

[4] M.Cao: A Preliminary Study on the Training Mode of Innovative and Entrepreneurial Talents in Applied Undergraduate Colleges and Universities[J], China University Teaching, 2011,(11):35-36.(In Chinese)

[5] L.Q.Yang and W.R.Li: Investigation and Analysis on the Current Situation of the Training of Innovative and Entrepreneurial Talents in Colleges and Universities[J], The Party Building and Ideological Education in Schools, 2017,(16):80-82.(In Chinese)

[6] A.H.Wu, Y.F.Hou, J.Hao, etc: The Deepening of Educational Reform of Innovation and Entrepreneurship in Colleges and Universities Taking "Internet+" Innovative and Entrepreneurial Competition as the Carrier[J], China University Teaching, 2017,(1):23-27.(In Chinese)

[7] Q.L.Liao and X.X.Meng: The Practice and Exploration of Innovation and Entrepreneurship Education Mode in Colleges and Universities[J], The Party Building and Ideological Education in Schools, 2017,(4):74-75,93.(In Chinese) 